\title{
REDUCING POVERTY THROUGH SUBSIDIES: SIMULATION OF FUEL SUBSIDY DIVERSION TO NON-FOOD CROPS
}

\author{
Indra Maipita ${ }^{1}$ \\ Wawan Hermawan
}

Fitrawaty

\begin{abstract}
This paper analyzes the impact of fuel subsidy diversion to Non-Food Crops sector on income levels, using AGEFIS; a Computable General Equilibrium model. Then we proceed to apply the FosterGreer-Thorbecke (FGT) index to measure the indicators of poverty (head count index, poverty gap index and poverty severity index). The simulation result shows the fuel subsidy diversion to Non-Food Crops sector provides a positive impact on increasing household incomes and poverty reduction. Furthermore, the fuel subsidy diversion to Non-Food Crops sector reduces the poverty of rural household, larger than the urban households.
\end{abstract}

Keywords: Subsidy, poverty, computable general equilibrium, AGEFIS.

JEL Classification: C68, E62, 132

1 Indra Maipita adalah dosen pada Fakultas Ekonomi, Universitas Negeri Medan, (Telp.: +6261-6613365, E-mail: imaipita@gmail.com); Wawan Hermawan adalah dosen pada Departemen Ekonomi Fakultas Ekonomi, Universitas Padjadjaran Bandung, (Email:wawan.hermawan@fe.unpad.ac.id) ; dan Fitrawaty adalah dosen pada Fakultas Ekonomi, Universitas Negeri Medan (Email: fitra53@gmail.com). 


\section{PENDAHULUAN}

Bahan Bakar Minyak (BBM) merupakan satu dari beberapa komoditi yang sangat berpengaruh terhadap komoditi lainnya. Perubahan harga BBM akan berdampak secara langsung maupun tidak langsung terhadap harga komoditi lainnya termasuk komoditi pokok seperti sandang, pangan dan papan, bahkan pada tingkat pendapatan dan kemiskinan. Untuk melindungi masyarakat miskin dan hampir miskin, pemerintah perlu melakukan intervensi terhadap harga BBM dengan cara memberikan subsidi.

Namun kenaikan harga minyak dunia yang sangat drastis sejak tahun 2008 (Reyes, at.al, 2009; FAO, 2008), bergesernya posisi Indonesia dari pengekspor minyak menjadi pengimpor minyak, serta terus bertambahnya kebutuhan terhadap BBM membuat beban subsidi semakin membengkak dan terus berkontribusi menekan APBN menjadi defisit. Selain itu berbagai kajian mengatakan bahwa subsidi BBM kurang tepat sasaran karena banyak dinikmati oleh kalangan yang tidak miskin.

Isu subsidi BBM telah menjadi diskusi hangat dengan berbagai topik, sepertise berapa besar beban subsidi BBM terhadap anggaran negara? Apakah subsidi BBM tepat sasaran? Apakah subsidi BBM merupakan kebijakan yang perlu diteruskan?Bagaimana strategi untuk keluar dari perangkap subsidi BBM?

Untuk meringankan beban anggaran, pemerintah Indonesia telah mengambil berbagai langkah kebijakan fiskal seperti penghapusan subsidi BBM secara bertahap. Berdasarkan Keppres (Keputusan Presiden) No. 55/2005, subsidi BBM yang masih tersisa akan dihapuskan walaupun waktunya belum ditentukan (Word Bank, 2005). Hal ini akan memicu kenaikan harga komoditas lainnya, menimbulkan inflasi, menekan daya beli masyarakat (pendapatan riil) serta dapat bermuara pada bertambahnya angka kemiskinan.

Kemiskinan masih merupakan persoalan yang krusial dan fenomena yang sangat kompleks bagi setiap Negara (Hung and Makdissi, 2004; Marianti dan Munawar, 2006; maipita et al,2010). Bahkan Pengentasan Kemiskinan telah menjadi tujuan utama kebijakan publikdi hampir semua negara industri (Moller, at.al, 2003), sehingga pemerintah di masing-masing negara berusaha untuk mengurangi persoalan tersebut melalui instrumen fiskalnya.

Terdapat beberapa fakta terkait tingkat kemiskinan dan sektor pertanian; (1) sektor pertanian, perkebunan, dan perikanan merupakan sektor usaha yang paling tinggi angka kemiskinannya serta mempunyai besaran elastisitas kemiskinan terhadap pertumbuhan ekonomi yang paling tinggi, (Suselo dan Tarsidin, 2008), (2) pengalaman pada saat krisis moneter tahun 1998 menunjukkan bahwa sektor Pertanian merupakan satu dari sedikit sektor yang bertahan terhadap krisis, (3) sektor Pertanian menghasilkan pangan dan bahan baku untuk sektor industri dan jasa, (4) penyerapan tenaga kerja di sektor pertanian sangat fleksibel, sehingga sektor pertanian dapat berfungsi sebagai jaring pengaman (survival sektor) dalam keadaan darurat (Stringer,2001; Hafizrianda, 2007; Bautista 2000; Maipita et al, 2010; Maipita, 2011). Selain 
itu, paradigma baru pembangunan pertanian menempatkan agricultural demand led sebagai strategi industrialisasi yang tepat untuk diterapkan dinegara berkembang (Susilowati, 2008).

Dari uraian di atas, timbul pertanyaan; bagaimana bila subsidi BBM tersebut dialihkan ke sektor Pertanian Tanaman Lainnya? Paper ini bertujuan untuk mengetahui dampak pengalihan subsidi BBM ke sektor Pertanian Tanaman Lainnya terhadap tingkat pendapatan dan kemiskinan di Indonesia.

Bagian selanjutnya dari paper ini akan mengulas teori. Bagian ketiga menyajikan metodologi dan data yang digunakan, sementara hasil simulasi dan analisisnya akan diberikan pada bagian keempat. Kesimpulan akan diberikan pada bagian kelima dan menutup peper ini.

\section{TEORI}

Secara umum, subsidi bertujuanuntuk menambah output, permintaan dan produktivitas serta menjaga stabilitas perekonomian, khususnya stabilitas harga. Dengan subsidi diharapkan bahan kebutuhan pokok masyarakat tersedia dalam jumlah yang mencukupi dengan harga yang stabil serta terjangkau olehd aya beli masyarakat (Nota Keuangan dan APBN, 2010; Handoko dan Patriadi, 2005; Norton, 2004; Kasiyati, 2010).

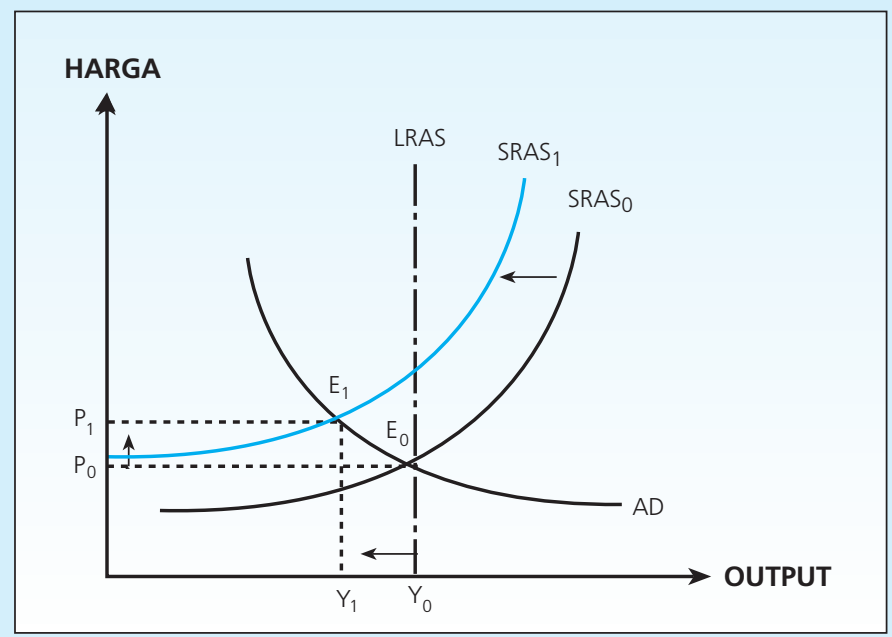

Grafik 1. Dampak Pengurangan

Subsidi BBM terhadap Keseimbangan Ekonomi

Menurut teori, pengurangan subsidi BBM akan berdampak terhadap harganya dan harga barang lain. Kenaikan harga inidapat memicu turunnya tingkat produksi (output). Seperti diperlihatkan pada Grafik 2, dalam jangka pendek pengurangan subsidi akan berdampak pada meningkatnya harga input, dengan kata lain terjadi peningkatan biaya produksi. Situasi 
ini akan menggeser kurva SRAS ke kiri (dari SRAS to SRAS $)$. Dengan asumsi bahwa permintaan agregatadalahtetap $\left(A_{0}\right)$, maka tingkat keseimbangan akan bergeser dari $E_{0} k_{1} E_{1}$, sehingga tingkat harga akan naik dari P0 ke P1 (cost push inflation) dan output berkurang dari $Y_{0} k e Y_{1}$.

Dampak dari subsidi pemerintah khususnya terhadap hasil pertanian diperlihatkan pada Grafik 2. Kurva penawaran produksi sektor pertanian jangka pendek diasumsikan bersifat inelastis (panel(a)). Bila pemerintah memberikan subsidi terhadap hasil pertanian, maka akan berdampak terhadap meningkatnya permintaan, kurva permintaan akan bergeser ke kanan atas dari $D$ ke $D^{s}$. Naiknya permintaan ini akan diikuti oleh kenaikan harga dari $P$ ke $P$, sebab dalam jangka pendek (SR) sektor pertanian tidak dapat menambah produksinya. Namun dalam jangka panjang $(\mathrm{LR})$, subsidi terhadap hasil pertanian akan dapat meningkatkan kuantitas yang ditawarkan, karena dalam jangka panjang kurva penawaran bersifat lebih elastis seperti diperlihatkan pada panel (b).

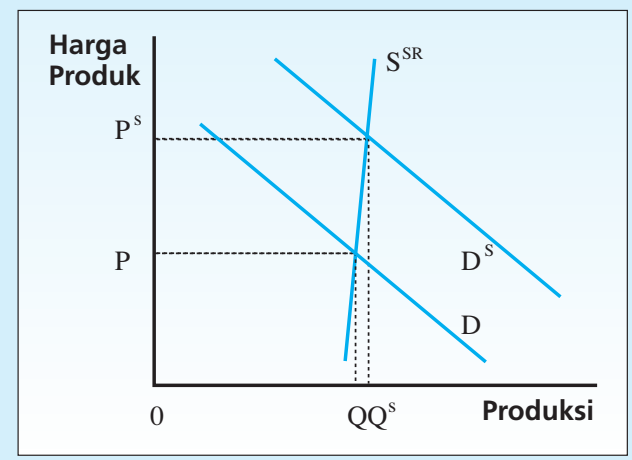

(a)

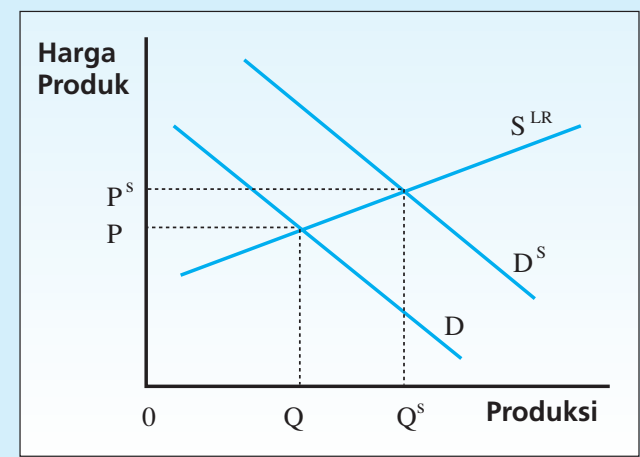

(b)

Grafik 2.

Dampak Subsidi terhadap Hasil Pertanian

Kebijakan pemberian subsidi biasanya dikaitkan dengan barang dan jasa yang memiliki eksternalitas positif dengan tujuan untuk menambah output. Ini merupakan efek positif dari subsidi. Sedangkan efek negatif dari subsidi bahwa subsidi dapat menciptakan alokasi yang tidak efisien karena konsumen membayar harga yang lebih rendah dari harga pasar sehingga ada kecenderungan konsumen tidak hemat dalam mengkonsumsi barang yang disubsidi. Selain itu, karena harga lebih rendah dari opportunity cost, maka dapat terjadi pemborosan dalam penggunaan sumber daya untuk memproduksi barang yang disubsidi (Spencer \& Amos, 1993). Subsidi yang tidak transparan dan tidak well-targeted dapat menyebabkan distorsi harga, inefisiensi dan tidak dinikmati oleh orang yang berhak (Basri, 2002).

Frame teori diatas merupakan keseimbangan parsial. Dalam kenyataan, perekonomian merupakan interaksi daribanyak pasar (mulai dari pasar input vs. pasar output dan pasar domestik 
vs. pasar luar negeri). Keseimbangan simultan ini juga melibatkan seluruh agen mulai dari rumah tangga, perusahaan, pemerintah dan pihak asing. Model computable general equilibrium (CGE) merupakan salah satu model yang mampu melihat interaksi simultan ini. Dalam paper ini, jenis model CGE yang digunakan adalah AGEFIS.

Secara umum, persamaan dalam model ini dibagi ke dalam enamblok, yaitu: (1) Domesticimport sourcing, yaitu persamaan yang berkaitan dengan komposisi permintaan menurut asal (domestik dan impor) yang didasarkan pada spesifikasi Armington, (2)Purchase'r price, yaitu persamaan yang menghubungkan harga produsen atau harga internasional dengan harga pembeli, (3) Demand for commodity, yaitu persamaan yang berkaitan dengan permintaan barang oleh berbagai pengguna, (4) Production sektor, berisi persamaan berhubungan dengan produksi baik barang maupun jasa, (5) Market clearing, berisi persamaan yang berhubungan dengan kondisi market clearing dimana penawaran sama dengan permintaan baik untuk komoditi maupun faktor produksi, (6) Institution, berisi persamaan yang yang berhubungan dengan pendapatan (income) dan pengeluaran institusi rumah tangga, pemerintah, perusahaan dan luar negeri.Masing-masing blok ini selanjutnya akan dijelaskan satu per satu.

\subsection{Domestic - Import Sourcing}

Para pelaku ekonomi ( wholesaler) akan berusaha untuk mengoptimalkan komposisi impor dan domestik dengan cara meminimalkan biaya dengan kendala fungsi aggregasi CES.

Min. : $\sum_{s} P Q(c, s) \cdot X D(c, s)$, dengan kendala:

S.t. $\quad X D_{-} S(c)=C E S(X D(c, s) \mid \sigma(c))=\left(\alpha(c, s) \sum_{S} \delta(c, s)^{-\rho(c)}\right)^{-\frac{1}{\rho(c)}}$

Dimana $P Q(c, s)$ adalah harga komsumen untuk komoditi $c$ dari $s, X D(c, s)$ adalah permintaan terhadap komoditi $c$, sumber $s, X D \_S(s)$ adalah permintaan terhadap komoditi komposit, $\alpha(c, s)$ adalah skala ekonomi, dan $\delta(c, s)$ adalah elastisitas substitusi.

Proses optimalisasi ini menghasilkan permintaan atas masing-masing komoditi $c$ oleh rumah tangga - XHOU_S(c), oleh industri sebagai input antara - XINT_S(c,i), oleh pemerintah - XG_S(c) dan untuk investasi - XINV_S(c). Ini akan dijelaskan pada bagian lain.

\subsection{Harga}

Harga yang diterima oleh konsumen merupakan harga netto setelah dikenakan pajak dan atau subsidi. Oleh karena itu, harga yang diterima konsumen dapat dituliskan pada persamaan tingkat level berikut: 


$$
P Q(c, \text { dom") }=(1+T X(c)-S C(c)) \cdot P T O T(c)
$$

dengan $P Q(c$,"dom") harga domestik tiap komoditi $c$; $T X(c)$; pajak yang dikenakan tiap komoditi c; $S C(c)$ subsidi yang dikenakan untuk tiap komoditi $c$; dan PTOT (c) harga komposit untuk komoditi $c$. Harga impor berhubungan dengan harga internasional, tarif dan nilai tukar, dan dapat diformulasikan sebagai:

$$
P Q(c, “ i m p ”)=E X R \cdot(1+t m(c)) \cdot P F I M P(c)
$$

dengan $P Q(c$,"imp") adalah harga impor untuk tiap komoditi $c$ (dalam mata uang domestik), EXR adalah nilai tukar, tm (c) tarif impor untuk tiap komoditi $c$, dan PFIMP (c) adalah harga komoditi $c$ diluar luar negeri (dalam mata uang asing).

\subsection{Sektor Produksi}

Pada prinsipnya dalam berproduksi, perusahaan berupaya memaksimumkan keuntungan dengan kendala teknolgi produksi seperti diperlihatkan pada Bagan 1. Input produksi pada model ini dibagi menjadi dua bagian, yaitu input dari faktor produksi primer komposit yang

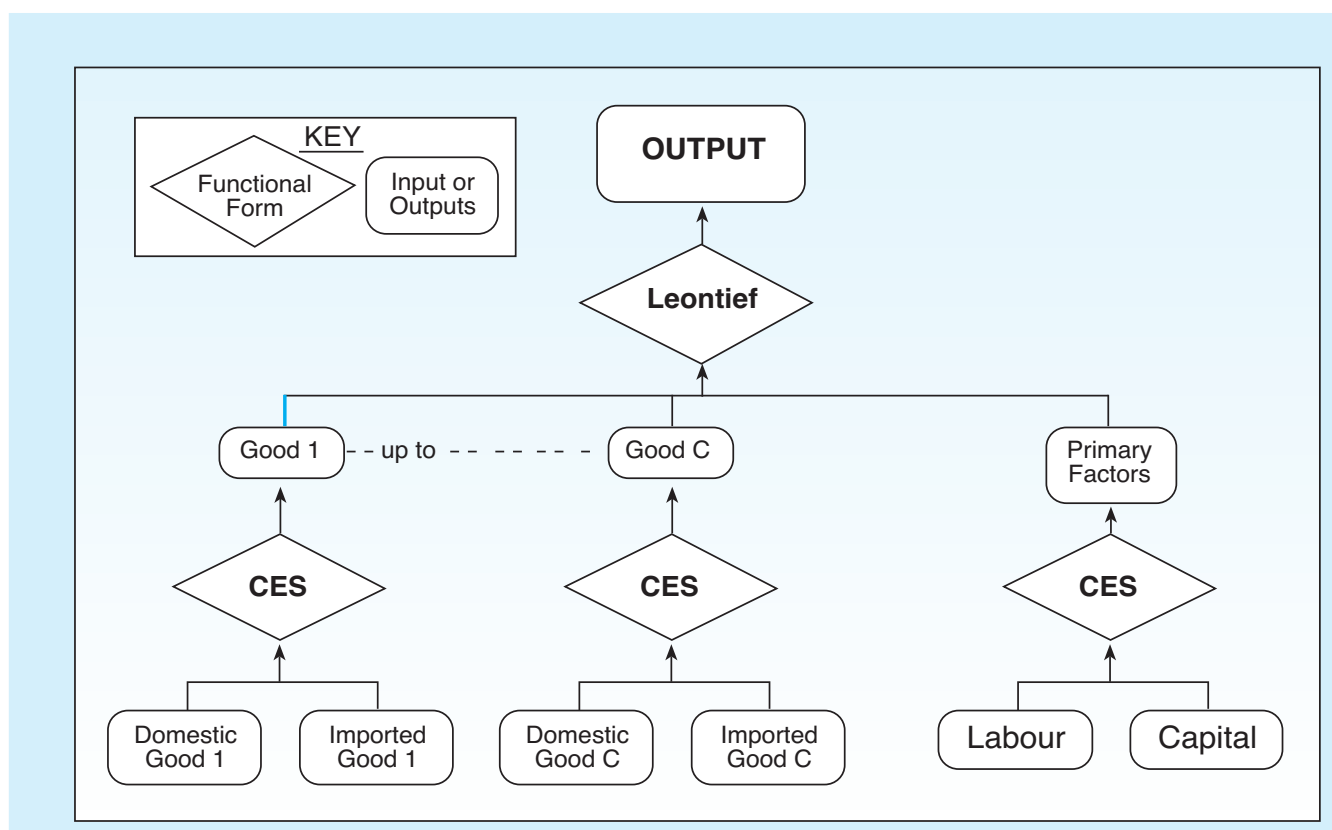

Sumber: BKFDK-RI, 2008a; Yusuf elt al, 2007

Bagan 1. Struktur Produksi 
terdiri dari tenaga kerja (labor) dan modal (capital) serta input dari barang antara (intermediate goods) yang juga komposit dari domestik dan impor. Konsekuensi dari penggunaan fungsi CES-Leontief adalah setiap permintaan input merupakan proporsi langsung terhadap output.

Dalam berproduksi, setiap industri membutuhkan input primer yang dalam spesifikasi model AGEFIS terdiri dari tenaga kerja dan modal. Persamaan permintaan faktor produksi diperoleh dari minimalisasi biaya dengan kendala fungsi produksi CES.

$\min : \quad \sum_{f} \operatorname{WDIST}(f, i) \cdot \operatorname{PFAC}(f) . X F A C(f, i)$, dengan kendala:

$$
\text { S.t. } \quad X P R I M(i)=\left[\sum_{f} \delta_{f}\left(\frac{X F A C(f, i)}{A F A C(f, i)}\right)^{-\rho}\right]^{-\frac{1}{\rho}}
$$

dengan XFAC $(f, i)$ adalah demand for factor $f$ by industry $i$, PFAC $(f)$ adalah harga faktor produksi $f$, WDIST $(f, i)$ adalah distortion premium untuk faktor $f$ pada industri $i$, dan XPRIM (i) adalah total nilai tambah yang merupakan komposit tenaga kerja dan modal.

Selain input primer, proses produksi juga membutuhkan input antara XINT_S $(c, i)$ yakni komoditi $c$, yang merupakan komposit komoditi impor dan domestik. Spesifikasi permintaan setiap industri $i$ untuk komoditi $c$ ini akan dijelaskan pada bagian selanjutnya bersama dengan permintaan dari pelaku ekonomi lain yakni rumah tangga, pemerintah dan permintaan untuk investasi.

Sebagaimana model CGE lainnya, dalam model AGEFIS, fungsi total produksi masingmasing industri dipresentasikan oleh fungsi Leontief. Alasan penggunaan fungsi iniadalah karena input primer dan input antara tidak dapat saling menggantikan, dan fungsi Leontief merupakan representasi dari hubungan komplementer sempurna diantara item yang membentuknya. Persamaannya dispesifikasi sebagai berikut:

$$
\begin{aligned}
& \text { Min. } \quad \operatorname{PPRIM}(i) \cdot X P R I M(i)+\sum_{c} P Q_{-} S(c) \cdot X I N T_{-} S(c, i) \\
& \text { S.t. } \quad X T O T(i)=\frac{1}{A T O T(i)} \cdot \operatorname{MIN}\left[\text { all,c,com }: \frac{X I N T+S(c, i)}{\operatorname{AINT}(c, i)}, \frac{X P R I M(i)}{\operatorname{APRIM}(i)}\right]
\end{aligned}
$$

dimana PPRIM ( $i$ ) adalah harga primary factor composite menurut industri, XPRIM (i) adalah permintaan terhadap primary factor composite menurut industri, XINT_S $(c, i)$ adalah permintaan terhadap komoditi menurut industri, XTOT ( $i$ ) adalah output atau penawaran komoditi, ATOT (i) adalahall factors technical change, dan APRIM (i) adalah elastisitas Armington. 
Proses minimalisasi biaya di atas akan menghasilkan produk industry $i$, yakni XTOT(i):

$$
\frac{X I N T \_S(c, i)}{A T O T(i)}=X T O T(i)
$$

Total output dari industri ini akan dipasarkan di dalam negeri dan di luar negeri. Tergantung pada permintaan domestik dan asing, harga, nilai tukar serta faktor lainnya, maka setiap industri akan mencari kombinasi share pasar yang optimal. Dalam bentuk level, persamaan matematikanya dituliskan seperti persamaan (7).

$$
X \operatorname{XOT}(c)=X D(c, “ d o m ”)+X E X P(c)
$$

dengan XTOT(c) adalah total output komoditi $c$, yang dialokasikan untuk pasar domestik, $X D\left(c\right.$,"dom”), dan untuk pasar ekspor, $X E X P(c){ }^{2}$ Komponen dari permintaan domestic ini akan dijelaskan pada bagian selanjutnya.

\subsection{Institusi dan Permintaan Komoditas}

Permintaan terhadap barang komposit terdiri dari empat jenis, yaitu: (1) permintaan barang untuk investasi, (2) permintaan barang oleh industri untuk bahan baku, (3) permintaan terhadap barang untuk konsumsi rumah tangga, dan (4) permintaan terhadap barang oleh pemerintah. Struktur permintaan terhadap barang ini disarikan pada Bagan 2.

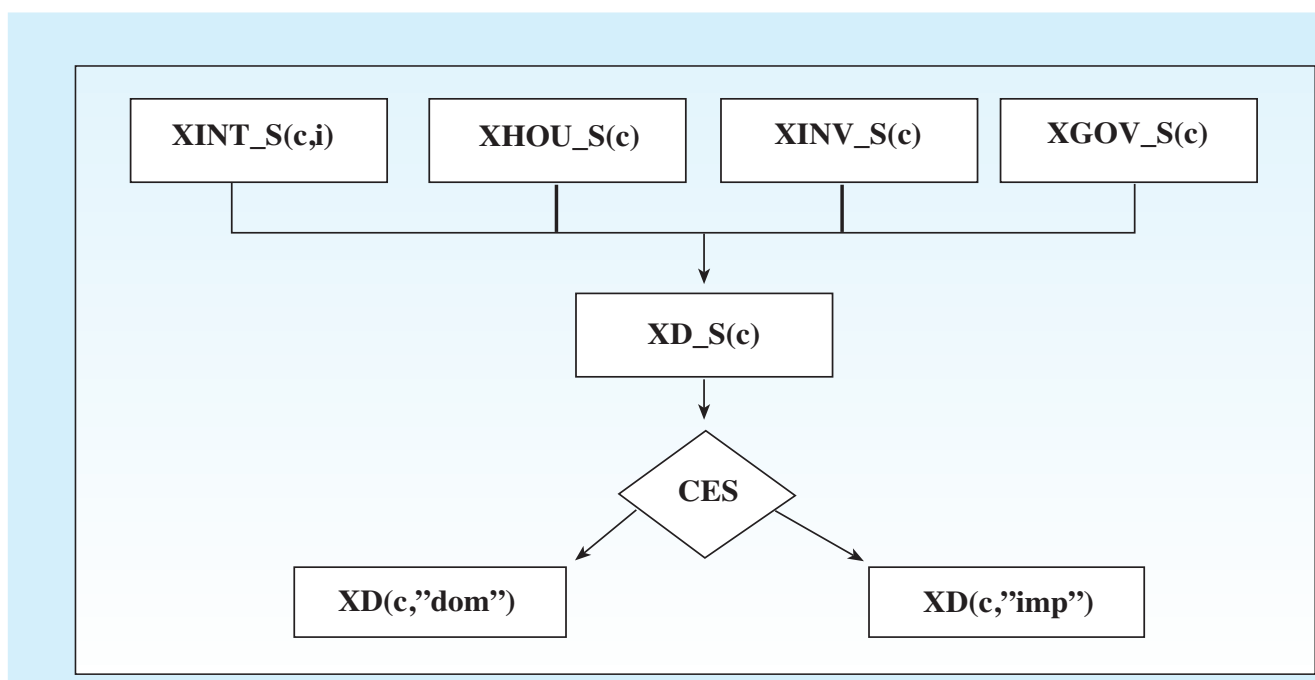

Sumber: BKFDK-RI, 2008a; Yusuf elt al, 2007

Bagan 2. Permintaan Terhadap Barang Komposit

2 Perlu ditekankan bahwa XD(c, "imp") merupakan permintaan domestik untuk barang impor. 
Permintaan industri untuk digunakan sebagai input antara telah dijelaskan pada bagian sebelumnya. Permintaan kedua adalah permintaan rumah tangga untuk konsumsi. Rumah tangga diasumsikan memaksimumkan utilitasnya dengan kendala anggaran yang ada. Sebagaimana institusi lainnya, rumah tangga dapat memilih dan mencari keseimbangan optimal antara pilihan komoditas satu dengan lainnya. Kemungkinan substitusi ini yang melandasi penggunaan fungsi agregator Cobb-Douglas seperti diperlihatkan pada Bagan 3. Terhadap pilihan asal komoditas, yaitu produk domestik dan impor, rumah tangga menentukan komposit komoditi $\mathrm{c}$ berdasarkan nesting CES sebagaimana telah dijelaskan sebelumnya.

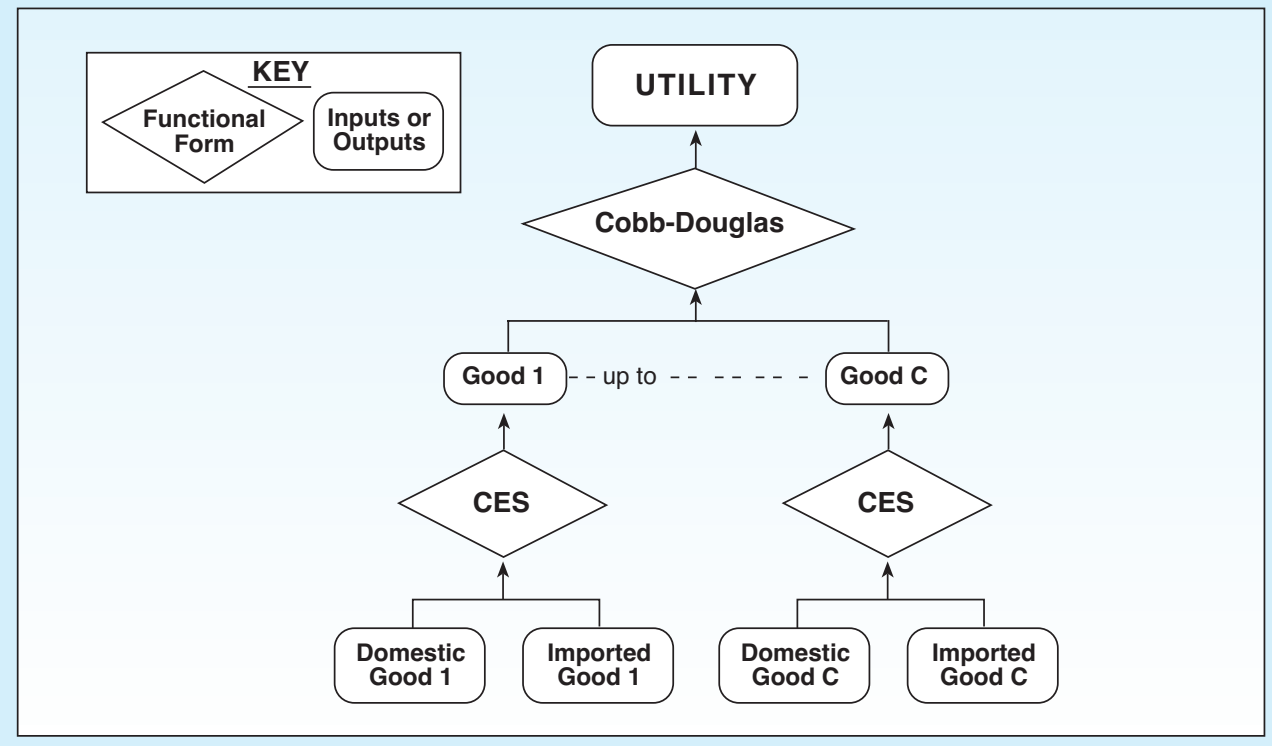

Sumber: BKFDK-RI, 2008a

Bagan 3. Permintaan Rumah Tangga

Rumah tangga memperoleh pendapatan dari kepemilikan atas faktor produksi. Selain itu, rumah tangga juga memperoleh pendapatan dari berbagai transfer yang bersumber dari: (1) pemerintah pusat, (2) perusahaan, (3) asing atau luar negeri, dan dari (4) rumah tangga lainnya. Dengan demikian dalam bentuk level, persamaan dari pendapatan rumah tangga didefinisikan pada persamaan (8).

$$
\begin{aligned}
Y H=\sum_{f} S F A C S H(f) Y F A C(f)+T R H O G O & + \text { TRHOCO } \\
& + \text { TRHORO + TRHOHO }
\end{aligned}
$$

Dengan : $Y H$ adalah pendapatan rumah tangga, SFACSH adalah share pendapatan dari faktor produksi. Hal ini terjadi kerena kepemilikan faktor produksi dalam suatu perekonomian 
bukan saja rumah tangga tetapi dapat juga perusahaan dan pemerintah. $Y F A C$ adalah faktor pendapatan, TRHOGO adalah transfer dari pemerintah ke rumah tangga, TRHOCO adalah transfer dari perusahaan ke rumah tangga (sebagai contoh, beasiswa dan corporate social responsibility), TRHORO adalah transfer dari rest of the world ke rumah tangga. TRHOHO adalah transfer antar rumah tangga.

Perimintaan ketiga dan kempat atas komoditi $c$ adalah pemerintah - $X G \_S(c)$ dan untuk investasi - XINV_S(c). Mengikuti penjelasan yang telah diberikan sebelumnya, kedua permintaan ini juga merupakan komposit atas komoditi impor dan domestik. Spesifikasi lebih lanjut untuk kedua permintaan ini tidak diulas dalam paper ini.

Setelah merinci keempat jenis permintaan atas setiap komoditi $c$, maka total permintaan domestik terhadap barang komposit dituliskan seperti persamaan (9).

$$
\begin{aligned}
X D \_S(c)= & \operatorname{sum}\left(i, X I N T_{-} S(c, i)+X H O U_{-} S(c)+X G \_S(c)\right. \\
& +X I N V_{-} S(c)
\end{aligned}
$$

dimana XD_S(c) total permintaan terhadap barang $c$, XINT_S(c) total permintaan barang $c$ oleh industri, $X H O U \_S(c)$ adalah total permintaan barang $c$ oleh rumah tangga, $X G \_S(c)$ adalah total permintaan barang $c$ oleh pemerintah, dan XINV_S(c) adalah total permintaan barang $c$ untuk investasi.

\section{METODOLOGI}

\subsection{Data dan Setting Simulasi}

Kajian ini menggunakan model keseimbangan umum (Computable General Equilibrium Mode), diadaptasi dari model AGEFIS (Applied General Equilibrium for Fiscal Policy), yang dikembangkan oleh Badan Kebijakan Fiskal Departemen Keuangan Republik Indonesia bekerjasama dengan Center for Economics and Development Studies (CEDs) Universitas Padjadjaran Bandung (BKFDK-RI, 2008;2008a; Yusuf et al, 2007).

Data yang digunakan dalam penelitian ini sebagian besar merupakan data sekunder, Social Accounting Matrix (SAM) Indonesia tahun 2005 dan data indikator kemiskinan tahun 2005. Faktor produksi diagregasi mejadi dua jenis, yaitu tenaga kerja dan modal. Sedangkan institusi dalam penelitian ini sama dengan institusi dalam SAM Indonesia 2005 yang terdiri dari rumah tangga, perusahaan dan pemerintah. Untuk keperluan analisis, rumah tangga pada Tabel SAM di aggregasi menjadi 4 kelompok, yang terdiri dari: (1) $\mathrm{HH}-1$, yaitu rumah tangga tidak miskin di kota, (2) $\mathrm{HH}-2$, rumah tangga miskin di kota, (3) $\mathrm{HH}-3$, rumah tangga tidak miskin di desa dan (4) $\mathrm{HH}-4$, yaitu rumah tangga miskin di desa. Sektor produksi yang digunakan terdiri dari 27 sektor yang diagregasi dari sektor produksi pada Tabel SAM Indonesia 2005. Yang termasuk ke dalam sektor Pertanian Tanaman Lainnya pada penelitian ini mengacu pada 
Klasifikasi Lapangan Usaha (KLU) Wajib Pajak 2003 (Nomor: KEP-34/PJ/2003, Tanggal: 14 Februari 2003), yang terdiri dari: (1) Perkebunan tebu dan tanaman pemanis lainnya, (2) Perkebunan tembakau, (3) Perkebunan karet dan penghasil getah lainnya, (4) Perkebunan tanaman bahan baku tekstil dan sejenisnya, (5) Perkebunan tanaman obat atau bahan farmasi, (6) Perkebunan tanaman minyak atsiri, (7) Perkebunan tanaman lainnya yang tidak diklasifikasikan di tempat lain, (8) Pertanian hortikultura sayuran yang dipanen sekali, (9) Pertanian hortikultura sayuran yang dipanen lebih dari sekali, (10) Pertanian hortikultura bunga-bungaan, (12) Pembibitan dan pembenihan hortikultura sayuran dan bunga-bungaan, (13) Pertanian buah-buahan musiman, (14) Pertanian buah-buahan sepanjang tahun, (15) Perkebunan kelapa, (16) Perkebunan kelapa sawit, (17) Perkebunan tanaman untuk bahan minuman, (18) Perkebunan jambu mete, (19) Perkebunan lada, (20) Perkebunan cengkeh, dan (21) Perkebunan tanaman rempah lainnya.

Simulasi kebijakan dilakukan dengan tiga skenario yang menggambarkan besarnya pengalihan subsidi yang dilakukan dalam persen. Simulasi $a$ berarti pengalihan subsidi dilakukan sebanyak 12.35 persen dari total subsidi BBM, simulasi $b$ sebanyak 43.2 persen dan simulasi $c$ sebanyak 100 persen.

Berkaitan dengan struktur fungsi produksi maka harus diketahui parameter elastisitas dari masing-masing fungsi yang digunakan; fungsi Leontief, Cobb-Douglas, dan CES. Koefisien elastisitas dari masing-masing fungsi tersebut dapat diestimasi atau dikutip langsung dari berbagai studi terdahulu yang dianggap relevan.

Besarnya dampak simulasi kebijakan terhadap tingkat pendapatan rumah tangga diperoleh dari hasil simulasi model CGE. Sedangkan untuk mengetahui dampak simulasi kebijakan terhadap angka kemiskinan digunakan metode pengukuran Foster-Greer-Thorbecke atau FGT index seperti yang digunakan oleh Sondan Kakwani (2004).

Jika rata-rata pendapatan meningkat sebesar $\psi$, maka pendapatan setiap rumah tangga dalam kelompok juga meningkat sebesar $\psi$. Dengan aturan ini, distribusi pendapatan secara proporsional akan bergeser secara horizontal di dalampendapatan. Aturan ini mengizinkan untuk membandingkan angka kemiskinan yang dihasilkan pada kasus sebelum dengan sesudah simulasi. Bentuk persamaan dari FGT inidapatdi lihat pada persamaan (10).

$$
P_{\alpha}=\frac{1}{n} \sum_{i=1}^{q}\left[\frac{g_{i}}{z}\right]^{\alpha} ; \alpha \geq 0 ; g_{i}=\frac{Z-y_{i}}{Z}
$$

dimana $y_{i}$ merupakan rata-rata pendapatan atau pengeluaran penduduk miskin dengan restriksi $g_{i}=0$ pada saat $y_{i}>z, n$ merupakan jumlah individu dalam populasi, $q$ adalah jumlah rumah tangga yang berada di bawah garis kemiskinan, $g_{i}$ adalah poverty gap dari rumah tangga kei, $z$ garis kemiskinan, $P_{\alpha}$ merupakan indeks kemiskinan menurut $F G T$ dan $\alpha$ adalah derajat kemiskinan yang bersifat arbitrer. 
Bila $\alpha=0$, maka $P_{0}$ disebut juga dengan head count index, menunjukkan proporsi penduduk yang berada di bawah garis kemiskinan, didefenisikan sebagai persentase jumlah penduduk miskin terhadap total penduduk. Bila $\alpha=1$, maka diperoleh indeks $P_{1}$. Indeks ini digunakan untuk mengukur kedalaman kemiskinan atau jurang kemiskinan (depth of poverty index) atau tingkat kesenjangan kemiskinan (poverty gap index). Indeks ini menggambarkan ukuran ratarata ketimpangan pengeluaran masing-masing penduduk miskin terhadap garis kemiskinan atau total kesenjangan dari seluruh rumah tangga dalam kelompok terhadap garis kemiskinan. Bila $\alpha=2$, maka diperolehindeks $P_{2}$. Indeks ini digunakan untuk megukur tingkat keparahan kemiskinan (poverty severity index).

\subsection{Closure}

Terdapat dua model closure standar yang digunakan dalam model ini, yaitu standard short run cloosure dan standard long run closure. Perbedaan keduanya terletak pada mobilitas faktor produksi.

Dalam short run closure, modal bersifat spesifik dimana ia tidak bisa berpindah lintas sektor. Dengan kata lain, kapital menjadi fixed input untuk setiap industri. Hal ini dapat dilakukan dengan membuat variabel permintaan kapital ( $x$ fac("capital", "IND)) di semua industri bersifat eksogen dan menjadikan variabel factor price distortion untuk kapital (wdist(“capital, IND)) tidak ada dalam model. (wdist("labor:, IND) tetap ada). Selain itu, diasumsikan terdapat nominal wage rigidity. Ini dilakukan dengan cara menempatkan total labor supply (xfacsup("labor")) sebagai variabel endogen dan membuat harga tenaga kerja (pfac("labor")) menjadi variabel eksogen.

Berbeda halnya dengan long run closure, total faktor produksi (labor dan capital) dianggap konstan sehingga ditempatkan sebagai variabel eksogen (fully employment), namun dapat berpindah lintas sektor. Karena itu, harga faktor produksi sama untuk semua sektor. Setting ini dilakukan dengan menjadikan variabel factor price distortionuntuksemua faktor produksi ( wdist $(\mathrm{f}, \mathrm{i})$ ) sebagai variabel endogen sedangkan variabel harganya bersifat eksogen. Pada closure ini, variabel seperti tarif , pajak, berbagai transfer, dan parameter teknologi juga bersifat eksogen sedangkan exchange rate menjadi numeraire.

\section{HASIL DAN PEMBAHASAN}

Subsidi merupakan pembayaran yang dilakukan pemerintah kepada perusahaan atau rumah tangga untuk mencapai tujuan tertentu yang membuat mereka dapat memproduksi atau mengkonsumsi suatu produk dalam kuantitas yang lebih besar atau harga yang lebih murah. Subsidi dapat berupa pembayaran transfer (seperti kupon makanan dan subsidi perumahan), dan bantuan pada sektor pertanian (Ericson, et.al, 1998). Dalam bentuk barang, subsidi untuk jenis barang tertentu dilakukan dengan menyediakan barang dengan jumlah 
tertentu kepada konsumen tanpa dipungut bayaran atau pembayaran dibawah harga pasar (Handoko dan Patriadi, 2005).

Di negara berkembang, subsidi penting sebagai instrumen fiskal untuk mendorong produktivitas dan peningkatan kesejahteraan rakyat (Norton, 2004). Subsidi merupakan bentuk transfer pemerintah yang efisien sekaligus sebagai alat redistribusi kesejahteraan antar penduduk dan antar produsen dengan konsumen. Inilah pokok pentingnya subsidi, sehingga pada perekonomian majupun masih menggunakan instrumen subsidi ini. Dari sisi institusi, pajak yang lebih rendah dan peningkatan subsidi dapat menaikkan pendapatan dan daya beli rumah tangga. Pendapatan yang lebih tinggi ini akan mendukung peningkatan konsumsi rumah tangga (Simorangkir \& Adamanti, 2010). Meski demikian, sebagaimana telah disebutkan sebelumnya, subsidi memiliki efek negatif yakni dapatmenciptakan alokasi yang tidak efisien, pemborosan dalam penggunaan sumberdaya, dan kemungkinannya untuk tidak tepat sasaran (Basri, 2002).

Secara keseluruhan, skenario kebijakan mengalihkan subsidi BBM ke sektor Pertanian Tanaman Lainnya (PTL) memberikan dampak positif terhadap peningkatan pendapatan semua kelompok rumah tangga (Tabel 1). Hal ini disebabkan karena sebahagian besar rumah tangga dari setiap kelompok berkaitan dengan sektor PTL, baik sebagai pekerja, pemilik lahan atau perkebunan maupun sebagai pengusaha dari hasil-hasil sektor ini. Rumah tangga di desa menerima dampak kenaikan pendapatan yang lebih besar dibanding dengan rumah tangga di kota. Hal ini disebabkan karena sebahagian besar sektor PTL berada di desa dimana sebahagian rumah tangga di desa bertindak sebagai pekerjanya bahkan ada yang sekaligus sebagai pemilik. Dari Tabel 1 terlihat bahwa semakin besar subsidi yang diberikan pada sektor ini maka semakin besar pula kenaikan tingkat pendapatan yang dialami oleh setiap rumah tangga.

Pengalihan subsidi ini meningkatkan aktivitas pada sektor yang penerima. Peningkatan pendapatan rumah tangga ini dapat disebabkan karena bergairahnya sektor ini, sehingga dapat membuka lapangan kerja yang lebih banyak. Banyak para ahli menyimpulkan bahwa pekerjaan adalah kunci untuk keluar dari kemiskinan, dan meningkatkan lapangan kerja sangat penting untuk mengurangi ketidakmerataan (Bluestone dan Harrison2000). Rumah tangga yang di dalamnya terdapat orang yang bekerja jauh lebih kecil kemungkinannya untuk menjadi miskin (Hills 2004;Lohmann2009).

\begin{tabular}{|c|c|c|c|}
\hline \multicolumn{4}{|c|}{$\begin{array}{l}\text { Tabel 1. Hasil Simulasi Pengalihan Subsidi BBM } \\
\text { ke Sektor PTL terhadap Tingkat Pendapatan Rumah Tangga (persentase perubahan) }\end{array}$} \\
\hline \multirow{2}{*}{ Rumah Tangga } & \multicolumn{3}{|c|}{$\begin{array}{ll}\text { Perubahan } \\
\end{array}$} \\
\hline & Sim_a & Sim_b & Sim_c \\
\hline $\mathrm{HH}-1$ & 0.4674 & 1.2544 & 16.7885 \\
\hline $\mathrm{HH}-2$ & 0.3224 & 0.5230 & 11.7780 \\
\hline $\mathrm{HH}-3$ & 0.5709 & 1.8104 & 20.5742 \\
\hline $\mathrm{HH}-4$ & 0.4589 & 1.3746 & 17.4994 \\
\hline
\end{tabular}


Kebijakan ini ternyata bukan hanya mampu menaikkan tingkat pendapatan semua golongan rumah tangga, tetapi juga mengurangi angka kemiskinan. Artinya kenaikan pendapatan yang diperoleh rumah tangga miskin telah mampu mengangkat mereka yang semula miskin atau berada sedikit di bawah garis kemiskinan menjadi berada di atas garis kemiskinan.

Dari Tabel 2 hingga Tabel 4 terlihat bahwa semakin besar pengalihan subsidi yang dilakukan, semakin besar pula dampaknya terhadap penurunan angka kemiskinan. Pengalihan subsidi sebesar 12,35 persen, dapat menurunkan angka kemiskinan sebesar $1.61 \%$ dari total rumah tangga miskin di kota ditambah dengan 2,18 persen dari total rumah tangga miskin di desa. Pengalihan subsidi sebesar 43,2 persen dapat menurunkan angka kemiskinan sebesar 2,35 persen dari total rumah tangga miskin di kota ditambah dengan 6,45 persen dari total

\begin{tabular}{|c|c|c|c|c|c|c|c|c|c|}
\hline \multirow{3}{*}{ FGT Index } & \multicolumn{8}{|c|}{$\begin{array}{l}\text { Tabel 2. Dampak Simulasi Kebijakan Pengalihan Subsidi BBM } \\
\text { sebesar } 12,35 \text { persen ke Sektor PTL terhadap Angka Kemiskinan }\end{array}$} & \\
\hline & \multicolumn{3}{|c|}{ Ba se line } & \multicolumn{3}{|c|}{ Sim_a } & \multicolumn{3}{|c|}{ Perubahan $(\Delta)$} \\
\hline & $\alpha=0$ & $\alpha=1$ & $\alpha=2$ & $\alpha=0$ & $\alpha=1$ & $\alpha=2$ & $\alpha=0$ & $\alpha=1$ & $\alpha=2$ \\
\hline $\mathrm{HH}-1$ & 0.0000 & 0.0000 & 0.0000 & 0.0000 & 0.0000 & 0.0000 & 0.0000 & 0.0000 & 0.0000 \\
\hline $\mathrm{HH}-2$ & 1.0000 & 0.1916 & 0.0577 & 0.9839 & 0.1890 & 0.0568 & -0.0161 & $-1.3477 \%$ & $-1.4855 \%$ \\
\hline $\mathrm{HH}-3$ & 0.0000 & 0.0000 & 0.0000 & 0.0000 & 0.0000 & 0.0000 & 0.0000 & 0.0000 & 0.0000 \\
\hline $\mathrm{HH}-4$ & 1.0000 & 0.1926 & 0.0620 & 0.9782 & 0.1890 & 0.0608 & -0.0218 & $-1.8969 \%$ & $-1.9095 \%$ \\
\hline
\end{tabular}

Tabel 3. Dampak Simulasi Kebijakan Pengalihan Subsidi BBM sebesar 43,2 persen ke Sektor Pertanian Tanaman Lainnya terhadap Angka Kemiskinan

\begin{tabular}{l|c|c|c|c|c|c|r|r|r}
\multirow{2}{*}{ FGT Index } & \multicolumn{3}{|c|}{ Ba seline } & \multicolumn{3}{c|}{ Sim_a } & \multicolumn{3}{c}{ Perubahan $(\Delta)$} \\
\cline { 2 - 9 } & $\alpha=\mathbf{0}$ & $\alpha=1$ & $\alpha=2$ & $\alpha=\mathbf{0}$ & $\alpha=1$ & $\alpha=2$ & $\alpha=\mathbf{0}$ & $\alpha=1$ & $\alpha=2$ \\
HH-1 & 0.0000 & 0.0000 & 0.0000 & 0.0000 & 0.0000 & 0.0000 & 0.0000 & 0.0000 & 0.0000 \\
HH-2 & 1.0000 & 0.1916 & 0.0577 & 0.9765 & 0.1874 & 0.0563 & -0.0235 & $-2.1736 \%$ & $-2.3977 \%$ \\
HH-3 & 0.0000 & 0.0000 & 0.0000 & 0.0000 & 0.0000 & 0.0000 & 0.0000 & 0.0000 & 0.0000 \\
HH-4 & 1.0000 & 0.1926 & 0.0620 & 0.9355 & 0.1820 & 0.0586 & -0.0645 & $-5.5292 \%$ & $-5.5882 \%$
\end{tabular}

Tabel 4. Dampak Simulasi Kebijakan Pengalihan Subsidi BBM sebesar 100 persen ke Sektor PTL terhadap Angka Kemiskinan (persentase perubahan)

\begin{tabular}{|c|c|c|c|c|c|c|c|c|c|}
\hline \multirow{2}{*}{ FGT Index } & \multicolumn{3}{|c|}{ Baseline } & \multicolumn{3}{|c|}{ Sim_a } & \multicolumn{3}{|c|}{ Perubahan $(\Delta)$} \\
\hline & $\alpha=0$ & $\alpha=1$ & $\alpha=2$ & $\alpha=0$ & $\alpha=1$ & $\alpha=2$ & $\alpha=0$ & $\alpha=1$ & $\alpha=2$ \\
\hline $\mathrm{HH}-1$ & 0.0000 & 0.0000 & 0.0000 & 0.0000 & 0.0000 & 0.0000 & 0.0000 & 0.0000 & 0.0000 \\
\hline $\mathrm{HH}-2$ & 1.0000 & 0.1916 & 0.0577 & 0.6443 & 0.1191 & 0.0336 & -0.3557 & $-37.8543 \%$ & $-41.7008 \%$ \\
\hline $\mathrm{HH}-3$ & 0.0000 & 0.0000 & 0.0000 & 0.0000 & 0.0000 & 0.0000 & 0.0000 & 0.0000 & 0.0000 \\
\hline $\mathrm{HH}-4$ & 1.0000 & 0.1926 & 0.0620 & 0.5160 & 0.1007 & 0.0308 & -0.4840 & $-47.7333 \%$ & $-50.3329 \%$ \\
\hline
\end{tabular}


rumah tangga miskin di desa. Sedangkan pengalihan semua subsidi BBM ke sektor PTL dapat menurunkan angka kemiskinan sebesar 35,57 persen dari jumlah rumah tangga miskin di kota dan 48,40 persen dari jumlah rumah tangga miskin di desa.

Dampak simulasi terhadap pengurangan kemiskinan di desa ternyata jauh lebih besar dibanding di kota. Hal ini disebabkan karena akses masyarakat desa terhadap sektor Pertanian Tanaman Lainnya secara langsung lebih besar dibandingkan dengan masyarakat miskin di kota, sehingga kenaikan pendapatan yang dirasakan oleh rumah tangga miskin di desa juga lebih besar dibanding dengan rumah tangga miskin di kota. Selain itu, struktur ekonomi di pedesaan lebih sederhana dibanding di perkotaan sehingga kesempatan untuk mendapatkan pekerjaan relatif lebih mudah. Inilah yang disebut Wilson (1996); Brady, et.al (2010) bahwa konsentrasi kemiskinan di kota sebagai akibat dari menghilangnya pekerjaan.

Analisis di atas menunjukkan bahwa untuk tujuan pengurangan angka kemiskinan, maka subsidi ke sektor Pertanian Tanaman Lainnya dapat diambil sebagai sebuah alternative kebijakan (ceteris paribus). Hal ini sejalan dengan kajian yang dilakukan Abimanyu (2000) yang menemukan bahwa sektor pertanian memberikan benefit yang lebih besar khususnya pada usaha perkebunan karet. Selanjutnya pemberian subsidi merupakan cara yang paling efektif diterapka nuntuk pengentasan kemiskinan di pedesaan, sebagaimana Ravallion dan Datt (1999) yang menyatakan bahwa peningkatan pertumbuhan sektor pertanian diyakini merupakan cara yang paling efisien dalam mengurangi ketidakmerataan pendapatan dan kemiskinan. Arndt,et.al (1998) juga mendukung kesimpulan ini dalam kajiannya dengan kesimpulan bahwa pengembangan sektor pertanian dapat mengurangi kemiskinan

Hasil penelitian dari Lembaga Penelitian Institut Pertanian Bogor (2002) menemukan bahwa model pembangunan pertanian Agriculture Based Development(ABD) dapat memacu pertumbuhan eknomi yang lebih tinggi.. Pertumbuhan sektor manufaktur penting bagi pertumbuhan secara keseluruhan bagi suatu negara, namun pertumbuhan sektor pertanian sangat penting bagi pertumbuhan employment dan pengurangan kemiskinan.

Bigsten dan Levin (2000) menyatakan bahwa beberapa elemen strategis yang dapat mengurangi kemiskinan antara lain outward-oriented strategy berupa pertumbuhan ekonomi yang dimotori ekspor, yang didasarkan pada manufaktur yang labor intensive, pembangunan pertanian dan daerah pedesaan. Bautista (2001), Jansen dan Tarp (2004), dan Susilowati (2008), mengemukakan bahwa konsep Agricultural Demand Led Industri alization, selain dapat meningkatkan kinerja ekonomi makro juga berperan dalam mengurangi kesenjangan pendapatan rumah tangga dan kemiskinan di pedesaan. Suselo dan Tarsidin (2008) menyimpulkan bahawa langkah yang paling tepat untuk mengurangi kemiskinan adalah dengan memberikan perhatian lebih pada sektor pertanian, perkebunan dan perikanan. 


\section{KESIMPULAN}

Paper ini memberikan dua kesimpulan, pertama, kebijakan pengalihan subsidi BBM ke sektor Pertanian Tanaman Lainnya memberikan dampak positif terhadap peningkatan pendapatan rumah tangga dan pengurangan angka kemiskinan. Kesimpulan ini memerlukan penelusuran lebih lanjut tentang sub sektor mana dari sektor Pertanian Tanaman Lainnya yang dominan mengurangi angka kemiskinan serta bagaimana mekanisme dari pengalihan subsidi tersebut. Kedua, secara umum kebijakan pengalihan subsidi BBM ke sektor pertanian memberikan dampak yang lebih baik bagi kelompok rumah tangga di desa dibanding dengan kelompok rumah tangga di kota. 


\section{DAFTAR PUSTAKA}

Abimanyu, A., 2000, Impact of Agriculture Trade and Subsidy Policy on the Macroeconomy, Distribution, and Environment in Indonesia: A Strategy for Future Industrial Development. The Developing Economies, 38(4): 547-571.

Arndt,C., Jensen, H. T. dan Tarp, F., 1998, Structural Characteristics of the Economy of Mozambique: SAM Based Analysis. http://www.econ.ku.dk/ derg/papers/article.pdf. Accessed on December, 6 2010.

Basri, F., 2002, The Economy of Indonesian: Challenges and Hopes toward the Increase the Economy of Indonesian. Erlangga, Jakarta.

Bautista, R. M., 2000, Agriculture-Based Development: A SAM Perspective on Central Vietnam. The Developing Economies, 34(1): 112-32.

Bautista, R.M., 2001, Agriculture-Based Development: A Sam Perspective on Central Vietnam. The Developing Economics, 39(1): 112-132.

Bigsten, Arne dan Levin, Jorgen, 2000, Growth, Income Distribution, and Poverty: A Review. Goteborg University Working Paper in Economics, No. 32.

BKFDK-RI (Board of Fiscal Policy Department of Finance of the Republic of Indonesia), 2008, The Development of Computable General Equilibrium Model: Training Module Session I, Center for Economics and Development Studies (CEDS), Faculty of Economics, University of Padjajaran Bandung.

BKFDK-RI (Board of Fiscal Policy Department of Finance of the Republic of Indonesia), 2008a, Applied General Equilibrium Model for Fiscal Policy (AGEFIS): Module of Capacity Development C GE Model Session II, Center for Eonomics and Development Studies (CEDS), Faculty of Economics, University of Padjajaran Bandung.

Bluestone, Barry dan Bennett Harrison, 2000, Growing Prosperity. New York: Houghton Mifflin. Brady, David., Andrew S. Fullerton., dan Jennifer Moren Cross, 2010, More Than Just Nickels and Dimes: A Cross-National Analysis of Working Poverty in Affluent Democracies. Social Problems, Vol. 57(4) November 2010:559-585.

Eriksson, Ross C, David L. Kaserman, dan John W. Mayo, 1998, Targeted and Untargeted Subsidy Schemes: Evidence from Postdivestiture Efforts to Promote Universal Telephone Service. Journal of Law and Economics, Vol. 41(2) October 1998: 477-502.

FAO, 2008, Soaring Food Prices: Facts, Perspectives, Impact and Actions Required. Paper prepared for the High-Level Conference on World Food Security: The Challenges of Climate Change and Bioenergy, Rome, 3-5 June 2008. 
Hafizrianda, Y., 2007, The Impact of Building Agriculture Sector on Income Distribution and

Regional Economics in Papua Province: An analysis of Balance System of Economics

Social.Ph.D. Dissertation. Bogor: Postgraduate Program, Bogor Agriculture Institute.

Handoko, R., dan Patriadi, P., 2005, The Evaluation of Subsidy Non-Fuel Policy. The Study of Economy and Finance.9(4).

Hills, John, 2004, Inequality and the State. New York: Oxford University Press.

Hung, Nguyen Manh dan Paul Makdissi, 2004, Escaping the Poverty Trap in a Developing Rural

Economy. The Canadian Journal of Economics / Revue canadienned'Economique, Vol. 37(1) Feb., 2004: 123-139.

Jansen, H.T. dan F. Tarf, 2004, On The Choice of Appropriate Development Strategy: Inside

Gained from CGE Modeling of the Mozambican Economy. Journal of African Economies, 13(3): 446-478.

Kasiyati, Sri, 2010, The Analysis of Subsidy Impact of Fertilizer Price on Production Sector and Household Income Level in Central Java, Journal of Organization and Management, Volume 6 (1), Maret 2010: 28-45.

Lembaga Penelitian IPB, 2002, Studi Perumusan Structural Adjustment Program dan Model

Pembangunan Pertanian di Indonesia. Bogor: Lembaga Penelitian, Institut Pertanian Bogor. Lohmann, Henning, 2009, Welfare States, Labor Market Institutions, and the Working Poor: A Comparative Analysis of 20 European Countries. European Sociological Review 25:489504.

Maipita, Indra., Mohd. Dan Jantan., dan Nor Azam Abdul Razak, 2010, The Impact offiscal Policy toward Economic Performance and Poverty Rate in Indonesia. Bulletin Monetary Economics and Banking: Bank Indonesia, Volume 12 (4), April 2010: 391-424.

Maipita, Indra, 2011, The Effect of Direct Cash Aid (BLT) Distribution Toward Income and Poverty Level in Indonesia.

Journal of Economic and Business, Research Institute Gunadarma University, Volume 16 (1), April 2011: 23-36.

Marianti,Ruly dan Wawan Munawar, 2006, Moving Out of Poverty: The Case of Desa Branta Pesisir, Pamekasan Regency. SEMERU Research Institute: Jakarta.

Moller, Stephanie, Evelyne Huber, John D. Stephens, David Bradley, Fran®dis Nielsen, 2003,

Determinants of Relative Poverty in Advanced Capitalist Democracies. American Sociological Review, Vol. 68(1) Feb., 2003: 22-51.

NKAPBN-RI. , 2009, Note of Finance and National Budget, The Fiscal Year 2010.

Norton, R.D., 2004, Agricultural Development Policy: Concept and Experiences. Food and Agricultural Organization and John willey and sons Ltd. West Sussex.

Ravallion, M. dan Datt, G. ,1999, When is Growth Pro-Poor? Evidence from the Diverse Experiences of India's States. World Bank.

Reyes, Celia M., Alellie B. Sobrevinas, Joel Bancolita and Jeremy de Jesus, 2009, Analysis of the Impact of Changes in the Price of Rice and Fuel on Poverty in the Philippines. Philippine Institute for Development Studies. Discussion Paper Series No. 2009-07 (March, 2009). 
Simorangkir, I. dan Adamanti J., 2010, The Roles of Fiscal and Relieving Monetary on Indonesian Economy during the Global Financial Crisis: Using the Approach of Financial Computable General Equilibrium. Bulletin of Monetary Economy and Banking Bank of Indonesia Vol. 13(2): 169-192.

Son, Hyun H., 2004, Measuring the Impact of Price Changes on Poverty. Working Paper International Poverty Centre United Nations Development Programme Number 33 November, 2006.

Stringer, R., 2001, How important are the Non-traditional Economic Roles of Agriculture in Development. Centre for International Economic Studies, Discussion Paper No. 0118, Adelaide University, Adelaide.

Suselo, S. L. dan Tarsidin, 2008, Poverty in Indonesia: The Effect of Growth and the Change of Economy Structure. Bulletin of Monetary Economy and Banking Bank of Indonesia, 11(2): 155-194.

Spencer, M. H., danAmos, O. M. Jr., 1993, Contemporary Economics. New York: Worth Publishers.

Susilowati, S. H., 2008, Strategy Agricultural Demand Led Industrialization from the Perspective of Economical of Work Increase and Farmer Income. Prespektif Peningkatan Kinerja Ekonomi, Research Forum of Agro Economy, Vol. 26 (1) July 2008: 44-57.

Wilson, W. J., 1996, When Work Disappears. New York: Norton.

Word Bank, 2005, The Study of Indonesian Public Outflow: Maximizing New Opportunities. Jakarta: Word Bank.

Yusuf, A. A., Hartono Djoni, and Wawan Hermawan, Y., 2007, AGEFIS: Applied General Equilibrium for Fiscal Policy Analysis. Working Paper in Economics and Development Studies No. 200807. Department of Economics, University of Padjadjaran. 
Halaman ini sengaja dikosongkan 